\title{
A competency-based approach to training non-native English speaking student volunteers for international sporting events
}

\author{
Olga D. Gladkova - Roza A. Valeeva - Olga A. Timakina - Fatima R. \\ Mirzoeva - Svetlana N. Khalevina
}

DOI: 10.18355/XL.2019.12.01.14

\begin{abstract}
Proficient training of students for participation in the organization and holding of mass sports events and the successful solution of various unforeseen situations that may arise in major competitions is a topical issue. The paper studies the challenges of designing and implementing the English language training volunteer program for a number of international mega sporting events. This program was organized and implemented on the basis of the 'actions-and-measures plan' directed towards the gradual development of the linguo-translational aspect of students' volunteer activity. The authors emphasize the essence and specifics of the English language training volunteer program, describe its initial phase, disclose its content and subject matter from the perspective of the competency-based approach in education, and present the procedure and the results of their experimental work to check and prove the effectiveness of the program.
\end{abstract}

Key words: English language training volunteer program, linguo-translational aspect, volunteer activity, competency-based approach, elective curriculum, e-course

\section{Introduction}

Nowadays, the major sporting events, including the World Cup 2018, are held and are going to be organized in the Russian Federation. One of the problems in organizing and holding significant sporting events is the proficient preparation of the necessary number of qualified volunteers. Proficient preparation of students for participation in the organization and holding of mass sports events and the successful solution of various unforeseen situations that may arise in major competitions is a topical issue. Being a volunteer of the major sporting events a person should possess not just only professional competencies, skills and knowledge in various functional areas such as spectator services, arrivals and departures, volunteer management, marketing, accommodation, catering, language services, but also wide range of soft skills (being a cheerful, flexible, dynamic person, willing to work hard and communicate with representatives of different cultures in national and international languages, living a healthy lifestyle, being stress-resistant, ready to study and assist). To participate in the international sporting event as a volunteer means to be part of a global highlight, to have a chance to represent the country and tell the world about it. The success of any significant international sporting events depends on the efficiency of volunteers.

Recently the volunteer culture and the studies concerning training student volunteers for International Sporting Events have not been developed and paid much attention in Russia. But in the past few years, due to a series of major international events, Russia has grown aware of what volunteers do and why their work is important. However, there is a necessity for selecting and implementing different methods and approaches to achieve better results in students' training for major international sporting events. It is essential to create special conditions and requirements for the integration of volunteer activities into the educational process.

Knowledge of the English language is an essential requirement for participation in international sporting events. Besides, the second foreign language (Spanish, French, German, Portuguese, and Arabic) is also essential. Global nature and enormous

XLinguae, Volume 12 Issue 1, January 2019, ISSN 1337-8384, eISSN 2453-711X 
educational and moral potential of sporting volunteering activity make it necessary to develop and integrate a special program into the curriculum of the "Foreign Language" discipline in a non-linguistic university, which will supplement the content of the training direction and satisfy the diverse cognitive interests of students that go beyond the major chosen by them. The foreign language teacher improves the ability to receive and disseminate information and knowledge. She/he creates an atmosphere of partnership and mutual interest in the students' success. The foreign language teacher cares about the students' development, about what they know and about how they understand the new language.

A competency-based approach to training non-native English speaking student volunteers for international sporting events is associated, first of all, with the formation of a minimum sufficient level of communicative competence in the pursuit of interpersonal and intercultural communication activity. The level should be sufficient to ensure that communication between the volunteers and the native speaker is adequate to the situation of communication. This communication involves familiarizing students with the features of intercultural communication, the basic patterns of the functioning of this style, its structural features. Assignments offered to students should be functionally applied and be designed for a conscious approach to the material being studied, to its logical assimilation. In addition, these tasks should involve the activation of linguistic and speech skills and abilities that contribute to the development of language and stylistic analysis of the expression of thought, as well as the formation of skills for constructing logical, etiquette literate and clear reasoning using the means of argumentation of one's own position within the given speech situation.

The essence of the competence approach is to help any person in the educational process to master key competencies, and not to introduce additional subjects, courses, electives, but through the proper construction of the educational process on any subject. The process of forming core competencies in the foreign language classes helps to form the competencies that help the student in sporting volunteering activity: readiness for autonomous reflection; critical thinking; problem solving; readiness for action; work with information; self-education; ability to cooperate; willingness to set goals; readiness for evaluation; determination of one's own position; use of various interactive tools. All core competencies have characteristics, they allow solving various problems during international sporting events, and therefore it is very important to master them for achieving important different goals and solving complex problems in different situations. Also, developing competencies associated with the acquisition of oral and written communication in the English classes, the students, as a basis, at the same time develop the ability of lifelong learning.

One of the main differences between the competency-based approach and dominating knowledge-based approach is that it integrates the reflective assessment and awareness of the boundaries of professional competence (Kalugina, 2016).

Despite the competency-based approach, we should consider the specifics of student volunteer training for sporting events of different kinds. It is fully reflected in simultaneous unity and independence of its three main aspects: linguo-translational, psychological-pedagogical, and organizational ones. Student volunteer training in accordance with all the three aspects leads to creating a huge breadth of knowledge and skills essential to organize and implement student volunteering (Serzhanova, 2015).

Lingvo-translational aspect is concerned with the challenges of the integrated English language volunteer training as well as the issues of intercultural dialogue in the context of tolerance and humanism, and practical approach to sporting vocabulary translation. There are also some vital and controversial aspects such as those connected with the challenges of overcoming the psychological barriers of 
intercultural communication (Song et al., 2017) and the selection of linguo-didactic material for the integrated English language training volunteer program.

Despite the fact that there exist numerous works analyzing various aspects of volunteering activity, however, the concept of a competency-based approach to training non-native English speaking student volunteers for international sporting events has not been elaborated. Thus, the purpose of the present research is to reveal the essence and specifics of the English language training volunteer program, describe its initial phase, disclose its content and subject matter from the perspective of the competency-based approach in education, and present the procedure and the results of the experimental work to check and prove the effectiveness of the program.

\section{Literature Review}

Today, volunteers are involved in logistics and tracking of all mass demonstration activities; they take part in the preservation and promotion of cultural heritage, creation of a new atmosphere of openness and accessibility of cultural spaces; they contribute to the development of social sphere, helping public and private social services agencies in carrying out their responsibilities for citizens' social security (Gorlova et al., 2016). The scientists assume that the concept of good quality volunteer training of sports specialty should include comprehensive training in several areas at the same time: psycho-pedagogic, linguistic and translational, organizational and management as well as knowledge of the rules of competition in such kind of sport in which a volunteer is planning to serve in the competition (Osipov et al., 2017).

A competency-based approach is considered to be efficient in training non-native English speaking student volunteers for International Sporting Events (Novikova, 2017), (Clifford - Thorpe, 2007). The competency-based approach allows forming the competencies necessary for the oral and written communication in volunteering activity. During English classes in a non-linguistic high school, Novikova (2017) offers to create an extracurricular language online environment (to get acquainted with volunteers from other countries in English-language forums). It is important to form the right ideas about the origins and foundations of volunteering using authentic sources, focused on creating a positive image of the volunteer and the public significance of his work. The discussion is intended to be one of the active methods of teaching in the foreign language classes, as it allows finding out and comparing the reasons and motivational attitudes that motivate people to engage in volunteer activity. Learning to communicate with representatives of a different culture is very important in modern conditions when the problem of intercultural differences and the formation of tolerance is acute (Novikova, 2017).

One of the most discussed aspects of student volunteering at the international sporting events is a linguo-translational aspect of this activity. A student volunteer with the knowledge of English is supposed to have not only English proficiency and some practical translation skills but also the integrated set of certain knowledge and skills for specific (sporting) purposes (Serzhanova, 2015). Today, the development of future specialists' professional foreign language communicative competence is known to become a priority in foreign language teaching.

Previous works have only focused on the translation process itself, not the teaching of it. Much research has been done in Europe and America in this respect. Translation theory represents more recent and, perhaps, more dramatic changes in notions of equivalence, faithfulness, the importance of context and function, translation strategies for different types of text, cultural interaction and conflict. The translation activity has a long-standing tradition and has been widely practiced throughout history, but in our rapidly changing world, its role has become of paramount importance. At present, knowledge in which cultural exchanges have been widening

XLinguae, Volume 12 Issue 1, January 2019, ISSN 1337-8384, eISSN 2453-711X 
has been increasingly expanding and international communication has been intensifying, the phenomenon of translation has become fundamental. Be it for scientific, medical, technological, commercial, legal, cultural, or sports purposes, today human communication depends heavily on translation and, consequently, interest in the field is also growing (El-dali, 2011). Translation is considered not only as a linguistic activity but as an intercultural communication activity in the economic, sport and many other spheres. Nevertheless, only a few researchers have addressed the problem of some practical ideas as to how to teach translation. The publications covering striking problems facing translation instructors - what to be taught, how to teach translation skills and strategies, and how to promote students' motivation to learn translation - are rather scarce. Teaching translation is a real problem since one has to teach translation skills, techniques, and doing translation practice, both oral and written, within a limited time span. (Alekseeva, 2000). Past translators generally adopted the traditional teacher-centered method which involved giving the students a text to translate and marking the resulting product in terms of "correctness." This method derives from the old Latin-based method, and many scholars have criticized it. Sorvali (1998) claims that "teaching translation in terms of correctness is not a teaching but a form of language testing, which is admittedly important but should not be an end in itself". Gouadec (2007) identifies three factors which define the teaching of translation: the perception of what the translators' functions are, the training context and the strategies.

Having studied the approaches to revealing and describing the essence and specifics of the linguo-translational aspect of professional and volunteering activity provided in the works by Verbitsky (2011), Goncharova (2008), Drandrov (2011), Panova (2014), Novikova (2015), Wang, Gorbunova, Masalimova, Birova, Sergeeva (2017), Li, Pyrkova and Ryabova (2017), Platonova, Zaitseva, Zemlyanskaya, Bezborodova, Stepanov, Mikhina (2017) we came to the conclusion that the integrated English language training volunteer program should develop:

- knowledge of vocabulary for specific purposes (English for Sports) to provide adequate communication on the issues connected with sporting event organization, hosting, participation, accreditation, doping-control, logistics, etc.

- knowledge of the vocabulary to provide a spotlight on the cultural and historical background of the geographical location where the sporting event is hosted

- knowledge of the vocabulary for certain specific purposes (Transport, Tourism, Catering, etc.) to provide effective communication on the issues of transportation, accommodation, and food provision for national teams, officials and sporting event guests

- ability to use specific terminology (both in Russian and English) essential to characterize the object of the issue (an international sporting event)

- ability to select and use the vocabulary correctly in accordance with the communicative tasks

- ability to produce a monologue within the thematic field (to present the facts in a logical order, to describe the events, to report information in a short form, to develop a theme, etc.)

- being ready to conduct a dialogue on specific and everyday topics in various communicative contexts (a "small talk," an inquiry dialogue, a dialogue stimulating to take actions, a dialogue as an information exchange tool, etc.).

\section{Methodology}

\section{A, Research methods}

The following methods were used in our research: theoretical (analysis of pedagogical, scientific and methodological literature on the challenges and issues of 
research, generalization, hypotheses or preliminary generalizations, system analysis and synthesis, comparison, analogy, classification); empirical (observation, oral interview in English, "Testing and Assessment Materials" prepared in accordance with the Federal State Educational Standards 3+ for such majors as "Physical Education" and "Tourism and Tourism Business", method of expert evaluation and assessment).

\section{B, Research Stages}

The initial stage of implementing the integrated English language training volunteer program for a number of sporting events.

At this stage taking into consideration, the types of volunteering activity pre-defined by the event organizing committee the aims, goals, and terms of implementing the integrated English language training volunteer program were defined and described, the prediction about the results was made.

The aim of our study is to design and implement the 'actions-and-measures plan' directed towards the gradual development of the linguo-translational aspect of students' volunteer activity.

The goals are as follows:

- to develop the Program for an elective e-course "English for International Sporting Events" (English Language Student Volunteer Training).

- to formulate the "unified glossary" for student volunteers taking part in international sporting events

- to create the elective intensive e-course "English for International Sporting Events" (English Language Student Volunteer Training) and publish it on the personal educational Internet site by Olga D. Gladkova 'Let's Study English: Feel Inspired.'

- to organize the recruitment and selection of the students to become volunteers for international sporting events by means of personal interviews in English taking into consideration the specifics of volunteering activity

- to conduct a serious of classes according to the integrated English language training volunteer program; to organize the exit monitoring of the linguo-translational aspect of students' volunteer activity.

\section{Discussion and Results}

A mention should be made that working on the content for the 'actions-and-measures plan' directed towards the gradual development of the linguo-translational aspect of students' volunteer activity we took into account the best and the most effective examples of teaching materials prepared by different groups of authors for international mega sporting events, such as the XXII Winter Olympic Games (Sochi, 2014), the XXVII World Summer Universiade (Kazan, 2013), the XXI FIFA World Championship (Central Russia, 2018), etc.

The analysis of Federal State Educational Standards for Higher Education (2016) showed that the competencies essential for student volunteers to take part in the international sporting event were still in the process of their defining. That is why while defining the essence and the content for the integrated English language training volunteer program we took as a starting point the general competencies from Federal State Educational Standards for the major

"Physical Training" such as:

- the ability to communicate orally and in the written form in Russian and English in order to solve the tasks of interpersonal and intercultural communication (General Competence-5)

- the ability to work in a team, to be tolerant to social, ethnical, confessional and cultural differences (General Competence-6)

XLinguae, Volume 12 Issue 1, January 2019, ISSN 1337-8384, eISSN 2453-711X 
- $\quad$ the ability for self-organization and self-education (General Competence-7).

"Tourism and Tourism Business" such as:

the ability to communicate verbally and in the written form in Russian and English in order to solve the tasks of interpersonal and intercultural communication (General Competence-3)

- the ability to work in a team, to be tolerant to social, ethnical, confessional and cultural differences (General Competence-4)

- $\quad$ the ability for self-organization and self-education (General Competence-5).

Taking into account the types of volunteering activity pre-defined by the event organizing committee together with the international recommendations for English language training for this category of workers it was decided to include into the elective intensive e-course "English for International Sporting Events" (English Language Student Volunteer Training) the following "must-be" thematic units:

- Volunteering. Classification of Volunteers

- The First World University Ski Orienteering Championship (WUSOC 2016)

- Glossary: General Sporting Vocabulary, Orienteering

- Glossary: Badges, Venue, Access Codes, General Information

- Glossary: General Terminology, Anti-Doping, Food and Beverage, Medical Issues, Media Operations

- Accommodation: Types of Accommodation

- Transport: Types of Transportation

- Catering: Types of Catering

- Host City: Tula

- Tula: Geography, History, Culture, and Traditions.

In the process of selecting and preparing the teaching material for the elective intensive e-course "English for International Sporting Events" (English Language Student Volunteer Training) and in accordance with the aim - to design and implement the 'actions-and-measures plan' directed towards the gradual development of the linguo-translational aspect of students' volunteer activity, we intentionally took an attempt to step aside from the grammar-based approach in teaching and move on to short and schematic explanation of conversational formula and clichés for everyday communication. Besides, alongside we tried to build the educational process in line with the communicative approach to a foreign language teaching and learning (Zimnyaya, 1989; Kolker et al., 2000; Grishaeva, 2015; Frolova et al, 2016; Pulverness et al., 2017) which is achieved when all the types of a foreign language communicative activity work together simultaneously (listening, writing, speaking and reading). Hence, student volunteer vocabulary and glossary as well as the use of the most frequent among the native speakers' words, phrases and clichés are trained and developed this way. By means of involving dilemma-oriented authentic texts we took an attempt to implement effective exercises to improve communicative skills both orally and in the written form as well as some basic translation skills.

It is logical to mention that the development of general competencies by means of the elective intensive e-course "English for International Sporting Events" (English Language Student Volunteer Training) was organized on the basis of authentic audio and video material to train and drill the skills for each thematic unit and a set of tasks for them (multiple choice, open cloze, odd one out, complete the sentence, true or false, etc.). The audio files from the media Internet sites (RT TV Network, Sputnik News Agency and Radio, Voice of America English News) are free to access and available to listen to; they were published in the elective intensive e-course "English for International Sporting Events" (English Language Student Volunteer Training) with the link to the source that does not interfere with the Russian Federation Copyright Law. 
The elective intensive e-course "English for International Sporting Events" (English Language Student Volunteer Training) was used to conduct a series of practical classes. Besides, the entry and exit monitoring of knowledge and skills were carried out according to the communicative approach to English teaching and learning.

Following the recommendations of the International Federation of University Sport (FISU) by means of the oral English interview method we selected 28 student volunteers with English skills out of 70 candidates. Among them, there were 24 bachelor's degree, master's degree and $\mathrm{PhD}$ degree students from the Department of Foreign Languages and four bachelor's degree students from the Department of Linguistics and Translation. With the help of this method, two experts from the Department of Foreign Languages defined the candidates' level of English: UpperIntermediate -15 volunteers, Intermediate - 13 volunteers. In identifying and assessing the level of English proficiency, the experts used the criteria to assess speaking skills suggested by IELTS, CPE, FCE international exams developers.

It should be emphasized that according to our aim - to design and implement the 'actions-and-measures plan' directed towards the gradual development of the linguotranslational aspect of students' volunteer activity and because of the limits of time, budget and human resources we didn't single out the control and the experimental groups.

Following the ideas presented in the works of Bespalko (1989) and Fomichyov (2014) we suppose that the effectiveness of the integrated English language training volunteer program can be assessed in accordance with the following criteria: 1) the goals of the educational process are reflected in the teaching content; 2) "information richness" of teaching aids - visibility and accessibility principles in education; 3) a multitude of teaching methods and variability and flexibility of teaching aids and techniques; 4) multipurposeness and usability of teaching aids; 5) commitment to reaching the "situation of success" in a collaborative activity of students and the teacher in implementing the integrated English language training volunteer program; 6) correlation and coordination of all the elements of the integrated English language training volunteer program; 7) visible improvements in students' achievements (their motivation, knowledge, skills, emotional state, etc.) while studying according to the integrated English language training volunteer program.

Before implementing intensive e-course "English for International Sporting Events" (English Language Student Volunteer Training) the entry test in written form was organized. It was done to define the students' level of English proficiency more accurately. For the purpose of the entrance testing, we used the "Testing and Assessment Materials" created by the Department of Foreign Language of Tula State University in accordance with the Federal State Educational Standards 3+ for such majors as "Physical Education" and "Tourism and Tourism Business." The results of the entrance testing are presented below in Table 1:

Table 1: Entrance levels of volunteers' English proficiency defined by means of the 100-point grading scale

\begin{tabular}{|c|c|c|}
\hline $\begin{array}{c}\text { Elementary/Beginner } \\
\text { Pre-Intermediate Levels } \\
(41-60 \text { points })\end{array}$ & $\begin{array}{c}\text { Intermediate } \\
\text { Level(61-80 points) }\end{array}$ & $\begin{array}{c}\text { Upper- } \\
\text { Intermediate/Advanced } \\
\text { Levels(81-100 points })\end{array}$ \\
\hline 0 student volunteers & 10 student volunteers & 18 student volunteers \\
\hline
\end{tabular}

The discrepancy in the results of the oral interview (Upper-Intermediate / Advanced Levels - 15 student volunteers) and the written testing (Upper-Intermediate / Advanced Levels - 18 student volunteers) can be explained by the testees' stress and

XLinguae, Volume 12 Issue 1, January 2019, ISSN 1337-8384, eISSN 2453-711X 
anxiety, time limits and still the traditions of the grammar-based approach to foreign language teaching and learning.

10 practical English classes were conducted by means of the elective intensive ecourse "English for International Sporting Events" (English Language Student Volunteer Training). Each class was two academic hours long and was conducted once a week in an interactive way. At these English classes an attempt was made to reach the maximum effectiveness according to these criteria: multipurposeness and usability of teaching aids in smart-education and commitment to reaching the "situation of success" in a collaborative activity of students and the teacher in implementing the integrated English language training volunteer program. Ten practical English classes for student volunteers were accompanied by their regular English classes according to their majors and curriculum.

After ten practical English classes both the exit written testing and the additional interview in English were carried out, with the latter organized to define and assess the qualitative changes in student volunteers' English proficiency. The results are presented in Tables 2 and 3.

Table 2: The level of English proficiency defined by means of oral interview method

\begin{tabular}{|c|l|l|}
\hline $\begin{array}{l}\text { Elementary/Beginner } \\
\text { Intermediate Levels }\end{array}$ & $\begin{array}{l}\text { Upper- } \\
\text { Intermediate/Advanced } \\
\text { Levels }\end{array}$ \\
\hline 0 student volunteers & 10 student volunteers & 18 student volunteers \\
\hline
\end{tabular}

Table 3: Exit levels of volunteers' English proficiency defined by means of the 100-point grading scale

\begin{tabular}{|l|l|l|}
\hline $\begin{array}{l}\text { Elementary/Beginner/Pre- } \\
\text { Intermediate Levels(41-60 } \\
\text { points) }\end{array}$ & $\begin{array}{l}\text { pointermediate Level(61-80 } \\
\text { Upper- } \\
\text { Intermediate/Advanced } \\
\text { Levels(81-100 points) }\end{array}$ \\
\hline 0 student volunteers & 8 student volunteers & 20 student volunteers \\
\hline
\end{tabular}

It can be seen, the implementation of the integrated English language training volunteer program resulted in positive qualitative changes in knowledge and skills of the student volunteers. The entrance and oral exit interviews in English showed that the number of student volunteers with the Upper-Intermediate / Advanced levels of English increased by $10 \%$. According to the results of the exit written testing, the number of volunteers with the Upper-Intermediate / Advanced levels of English increased by $7 \%$. The results are quite positive, although this fact can be explained by the relatively small number of groups under the experiment.

\section{Conclusion}

Thus, student volunteering at the international sporting events requires from the students a set of certain skills, such as to be ready to conduct their volunteering activity in both Russian and English in different situations of various social context, to be able to adapt as soon as possible to the ever-changing conditions of their volunteering activity, to be ready to use their knowledge and skills in a strategic and creative way so as to solve the organizational tasks. The integrated English language training volunteer program and the elective intensive e-course "English for International Sporting Events" (English Language Student Volunteer Training) in particular were used to train non-native English speaking student volunteers for a number of international mega sporting events. They resulted in the development of the 
linguo-translational aspect of student volunteering activity at a relatively high level. The experts, the coordinators of the student volunteer movement, the national teams and officials and the representatives of the International Federation of University Sport (FISU) recognized that the 'actions-and-measures plan' directed towards the gradual development of the linguo-translational aspect of students' volunteer activity proved to be effective.

\section{Acknowledgments}

1. The authors would like to thank their colleagues from the Institute of Pedagogics, Physical Education, Sport and Tourism of Tula State University; assoc. prof. Maria S. Leontyeva, the head of the Institute, and prof. Zoya I. Konnova, the head of the Department of Foreign Languages of the University for their insights and comments on an earlier version of the manuscript that appeared to be very helpful. This research was partially supported by the Organizing Committee of the First World University Ski Orienteering Championship.

2. The work is performed according to the Russian Government Program of Competitive Growth of Kazan Federal University.

\section{Bibliographic references}

ALEKSEEVA, I.S. 2000. Professional Training for Translators. St-Petersburg: IFL.192p. ISBN -6 C).

BESPALKO, V.P. 1989. Components of pedagogical technology. Moscow. 192 p. ISBN 978-5-7695-3930-5.

CLIFFORD, J. - THORPE, S. 2007. Workplace Learning and Development: Delivering Competitive Advantage for your organization. Available online: https://books.google.com.vc/books?id=CZzF-0_PMWUC\&printsec=frontcover

DRANDROV, G.L. 2011. Pedagogical conditions of developing a foreign-language communicative competence of future foreign language teachers on the basis of groupwork method. In: Vestnik CHGPU. Cheboksary, vol. 2, n. 4 (72), pp. 37-42. ISSN 1680-1709.

EL-DALI, H.M. 2011.Towards an understanding of the distinctive nature of translation studies. In: Journal of King Saud University - Languages and Translation, vol. 23, n. 1, pp. 29-45.ISSN 2210-8319.

FEDERAL STATE EDUCATIONAL STANDARDS OF HIGHER EDUCATION. 2016. Available online: http://минобрнауки.pф?keywords=114

FOMICHYOV, R.S. 2014. Criteria and indicators for effective implementation of modern pedagogical technologies in the process of higher education modernization. In: Research in Humanities, n. 11. Available online: http://human.snauka.ru/2014/11/8352

FROLOVA, V.P. - KALUGINA, O.A. - ARTAMONOVA, L.S. - BOYKOV, A.I. 2016. Studying the practice of performance assessment and rating system implementation in higher institutions. In: IEJME: Mathematics Education. vol. 11, n. 5, pp. 1185-1193. ISSN 1306-3030.

GONCHAROVA, N.A. 2008. Creating a linguistic competency in a foreign-speaking communicative environment. In: Higher Education in Russia, Moscow, n. 9. pp. 162165. ISBN 0869-3617.

GORLOVA, N. I. - TROSKA, Z. A. - KRUTITSKAYA, Y. V. - GUREYEVA, Y. A. 2016. The Practice of Teaching Volunteers with Skills of Deaf Communication to Participate in the XVIII Deaflympics Winter Games: Research and Results. In: Indian Journal of Science and Technology, vol. 9(48). Available online: http://www.indjst.org/index.php/indjst/article/viewFile/94525/77210

GOUADEC, D. 2007. Translation as a profession. Amsterdam: John BenjaminsPublishing. 396 p. ISBN $9027216819,9789027216816$.

XLinguae, Volume 12 Issue 1, January 2019, ISSN 1337-8384, eISSN 2453-711X 
GRISHAEVA, E.B. 2015. Communicative approach in a diachronic aspect: for and against. In: International Journal of Applied and Fundamental Research, n. 4-5, pp. 582-585. ISBN 1996-3955.

KOLKER, YA.M. Practical model of teaching a foreign language. Moscow. 2000.

LI, N. - PYRKOVA, K.V. - RYABOVA, T.V. 2017. Teaching Communication Skills and Decision-Making to University Students. In: EURASIA Journal of Mathematics, Science and Technology Education, vol. 13, n. 8, pp. 4715-4723. ISSN 1305-8215.

NOVIKOVA, E.YU. 2015. Sociability of a translator-guide as a factor of intercultural excursion discourse. Vestnik TGU, n. 4, pp. 120-127. ISSN-L 1561-7793

NOVIKOVA, E.Yu. 2015. Sociability of a translator-guide as a factor of intercultural excursion discourse. In: Vestnik TGU, n. 4. pp. 120-127.

NOVIKOVA, Yu. V. 2017. Increase of the level of English language proficiency by students of a non-linguistic high school for the purpose of volunteer work at the World Football Championship in Russia. In: Scientific and Methodical Electronic Journal "Concept," pp. 83-86. Available online: http://e-koncept.ru/2017/770438.htm. OSIPOV, A. - ZHAVNER, T. - KLIMUK, Y. - KUDRYAVTSEV, M. VAPAEVA, A. - SALYAMOVA, P. - BLIZNEVSKIY, A. - BLIZNEVSKAYA, V. 2017. Training criteria of the sports specialty volunteers for the service support during winter sports competitions. In: Journal of Physical Education and Sport ${ }^{\circledR}$ (JPES), vol. 17, n. 2, pp. 942-947. ISSN 2247-8051.

PANOVA, A.N. 2014. Development of professional competency of an interpreter at the final stage of teaching a foreign language by means of game modeling. In: Vestnik IGLU sovershenstvovanie. n. 1 (26). Available online: http://cyberleninka.ru/article/n/ -professionalnoy-kompetentsii-ustnogo-perevodchika-na-zavershayuschem-etape-

obucheniya-sredstvami-igrovogo

PLATONOVA, R.I. - ZAITSEVA, N.A. - ZEMLYANSKAYA, E.N. BEZBORODOVA, M.A. - STEPANOV, P.A. - MIKHINA, G.B. 2017. Nonlinear development of university pedagogical system: permanence of didactic tasks. In: Man in India, vol. 97, n. 14, pp. 159-171. ISSN 00251569.

RT TV Network. Available online: https://russian.rt.com/

SERZHANOVA, Zh. A. 2015. A linguo-translational aspect of volunteers training. In: Topical Issues of Translation. N. Novgorod. ALBA, Issue 5, pp. 211-215. ISBN 9785-905213-05-2

SONG, T. - USTIN, P.N. - POPOV, L.M. - MUDARISOV, M.M. 2017. The Educational Technology of Ethical Development for Students. In: EURASIA Journal of Mathematics, Science and Technology Education, vol. 13, n. 6, pp. 2095-2110. ISSN 1305-8215.

SORVALI, I. 1998. The Translator as a Creative Being with special regard to the translation of literature and LSP. In: Babel, vol. 44, n. 3, pp. 234-243. ISBN 44(3): 234-243.

SPUTNIK NEWS AGENCY AND RADIO. Available online: http://sputniknews.com/

VERBITSKY, A.A. 2011. Professionalism invariants: formation issues: monograph. Moscow. LOGOS. 288 p. ISBN 978-5-98704-604-3.

Voice of America English News. Available online: http://www.voanews.com/ WANG, S. - GORBUNOVA, N.V. - MASALIMOVA, A.R. - BÍROVÁ, J. SERGEEVA, M.G. (2018). Formation of Academic Mobility of Future Foreign Language Teachers by Means of Media Education Technologies. In: EURASIA Journal of Mathematics, Science and Technology Education, vol. 14, n. 3, pp. 959976. ISSN 1305-8215.

ZIMNYAYA, I.A. 1989. Psychological aspects of teaching speaking in a foreign language. Moscow. 222 p. ISBN 5-200-00793-3. 
Words: 5246

Characters: 37254 (20,7 standard pages)

Assoc. Prof. Olga D. Gladkova

Department of Foreign Languages

Tula State University

Prospect Lenina 92

300012 Tula

Russia

glad9246@yahoo.com

Prof. Roza A. Valeeva, Doctor of Education

Institute of Psychology and Education

Kazan (Volga region) Federal University

18 Kremlyovskaya Str.

420008 Kazan

Russia

valeykin@yandex.ru

Assoc. Prof. Olga A. Timakina, PhD

Department of Foreign Languages

National Research University of Electronic Technology

Shokina Square 1

124498 Zelenograd, Moscow

Russia

olga-timakina@rambler.ru

Professor.Fatima R. Mirzoeva, $\mathrm{PhD}$ in Education

English Language Department

Diplomatic Academy of the Ministry of Foreign Affairs of the Russian Federation Ostozhenka 53/2, stroenie 1

119021 Moscow

Russia

fatima_kalaeva@mail.ru

Assoc. Prof. Svetlana N. Khalevina, $\mathrm{PhD}$

Department of Foreign Languages

Financial University under the Government of the Russian Federation

Leningradsky prospect 49

125993 Moscow

Russia

snhalevina@ya.ru 